\title{
Biomarkers responses in muscle of Senegal sole (Solea senegalensis) from a heavy metals and PAHs polluted estuary
}

\author{
Milagrosa Oliva ${ }^{\mathrm{a}, *}$, José Antonio Perales $^{\mathrm{b}}$, Carlos Gravato ${ }^{\mathrm{c}}$, Lucia Guilhermino ${ }^{\mathrm{c}}$, \\ María Dolores Galindo-Riaño ${ }^{\mathrm{d}}$ \\ a Department Biology, Marine and Environmental Sciences Faculty, University of Cadiz, Puerto Real, Cadiz, Spain \\ ${ }^{\mathrm{b}}$ Department of Environmental Technologies, CACYTMAR, Andalusia Centre of Marine Sciences and Technology, Faculty of Marine and Environmental Sciences, \\ University of Cadiz, 11510 Puerto Real, Cadiz, Spain \\ ${ }^{\mathrm{c}}$ University of Porto, CIIMAR - Centro Interdisciplinar de Investigação Marinha e Ambiental, Rua dos Bragas 289, 4050-123 Porto, Portugal \\ ${ }^{\mathrm{d}}$ Department of Chemistry, Sciences Faculty, University of Cadiz, Puerto Real, Cadiz, Spain
}

\section{A R T I C L E I N F O}

\section{Keywords:}

Biomonitoring

LDH

IDH

AChE

Heavy metals

PAHs

Solea senegalensis

\begin{abstract}
A B S T R A C T
The biochemical responses in muscle, such as the enzymatic activities of acetylcholinesterase, lactate dehydrogenase and isocitrate dehydrogenase, were studied in sole (Solea senegalensis) collected in Huelva estuary (SW Spain), in the vicinity of a petrochemical and mining industry. The sampling sites showed different type and degree of pollution. The results demonstrated significant differences in muscle activities of AChE and IDH in Odiel and Tinto Rivers compared to control fish. LDH activity did not show any difference between sampling sites. Significant correlations were established between some biomarkers and heavy metals: AChE was correlated with $\mathrm{Pb}, \mathrm{Cd}$ and $\mathrm{Cu}$ concentrations in water; IDH activity was correlated with $\mathrm{Cd}$ and $\mathrm{Cu}$ concentrations in water and $\mathrm{As}, \mathrm{Pb}$ and $\mathrm{Cd}$ concentrations in sediments; $\mathrm{LDH}$ activity was correlated with As and $\mathrm{Zn}$ concentration in water and $\mathrm{Cd}$ concentration in sediment. Only one correlation was established between the biomarkers analysed and the concentrations of PAHs: benzo(b)fluoranthene concentration in sediment and IDH.
\end{abstract}

(c) 2012 Elsevier Ltd. All rights reserved.

\section{Introduction}

High concentrations of heavy metals and polycyclic aromatic hydrocarbons (PAHs) have been found in the Ría of Huelva, where Tinto and Odiel rivers flow into Atlantic Ocean together forming a common estuary (Jiménez-Tenorio et al., 2007; Vicente-Martorell et al., 2008, 2009).

PAHs derive from the incomplete combustion of fossil fuels, creosote production, discharges from electrochemical industry, such as, aluminum smelters, and oil spills. PAH-contaminated sediments can adversely affect biota or result in high concentrations in the tissues of indigenous organisms. Due to their high lipophilicity, they are also preferentially accumulated in the lipids of organisms. (Eisler, 2007).

Metals enter surface waters from a variety of sources including industry discharges, domestic sewage, non-point runoff, urban storm runoff and atmospheric precipitations. Metals encompass a wide range of non-degradable and highly persistent substances and also those bioaccumulate in organisms. (Eisler, 2007).

\footnotetext{
* Corresponding author. Address: Department of Biology, Marine and Environmental Sciences Faculty, University of Cadiz, Avda. República Saharaui S/N, Puerto Real 11510, Cádiz, Spain. Tel.: +34 956016016; fax: +34 956016019.

E-mail address: milagrosa.oliva@uca.es (M. Oliva).
}

It is well known that even moderate concentrations of certain PAHs and heavy metals in seawater and sediments can have a detrimental effect on aquatic organisms. The use of biomarkers in biomonitoring studies is commonly applied in order to elucidate the presence and effects of contaminants in the aquatic environment and to identify certain substances present at low levels (Van der Oost et al., 2003).

Acetylcholinesterase (AChE), lactate dehydrogenase (LDH) and isocitrate dehydrogenase (IDH) are induced by a variety of natural and synthetic compounds and play an important role in specific physiological functions (Van der Oost et al., 2003). Recent studies with aquatic animals have been relating swimming performance disturbances and those biomarkers involved in important physiological responses, such as, neurotransmission and energetic metabolism (Brewer et al., 2001; Castro et al., 2004; Gravato and Guilhermino, 2009; Almeida et al., 2010; Almeida et al., 2012).

Acetylcholinesterase (AChE) is responsible for the degradation of the acetylcholine neurotransmitter in cholinergic synapses. Pseudocholinesterases are involved in the detoxification of several xenobiotics decreasing their concentration in the organisms preventing AChE inhibition. The inhibition of AChE activity has been shown to have reflexes at the organism level and the diminished contribution of the affected individuals to the population (Hannam 
et al., 2008; Gravato et al., 2010; Almeida et al., 2010; Almeida et al., 2012).

Fish when facing a stress condition need an additional energy support. LDH is involved in the energy production through the anaerobic metabolism and provide useful information in relation to energy demand in organisms exposed to chemical stress (Sancho et al., 2009; Almeida et al., 2010). Since the aerobic metabolism can be also altered, the citric acid cycle enzymes can provide information in relation to energetic metabolism of the fish. IDH is an important enzyme due to its function in the aerobic pathway of energy production (Napierska and Podolska, 2008).

Several studies have successfully used the effects on AChE, LDH and IDH activities as tools to diagnose organophosphate and carbamate pesticide exposure in fish (Fulton and Key, 2001; Kopecka and Pempkowiak, 2004; Rendon von Osten et al., 2005; Whitehead et al., 2005; Ballesteros et al., 2009; Almeida et al., 2010), but only a few works have discussed the effects of heavy metals (Almeida et al., 2001, 2002; Romani et al., 2003; Antognelli et al., 2003; Napierska and Podolska, 2008; Vieira et al., 2009; Pretto et al., 2010) and PAHs (Roche et al., 2002; Napierska and Podolska, 2006; Vieira et al., 2008; Solé et al., 2008; Silva et al., 2009) on these biomarkers in fish muscle.

Solea senegalensis have been chosen for this study due to its great economic and commercial interest. It is also one of the most abundant and representative species of Atlantic and Mediterranean coasts. S. senegalensis is a well adapted species to warm climates and is commonly exploited in extensive aquaculture production in Spain and Portugal (Drake et al., 1984; Dinis, 1992). This species has been used in field and laboratory toxicity assays being a sensitive to heavy metals (Oliva et al., 2009; Costa et al., 2009).

The aim of the presented study was to investigate possible relationships between heavy metals and PAHs concentrations and biochemical parameters in muscle of sole, $S$. senegalensis. The biochemical markers considered were the activities of acetylcholinesterase (AChE), lactate dehydrogenase (LDH) and isocitrate dehydrogenase (IDH).

\section{Materials and methods}

\subsection{Sampling sites}

Tinto and Odiel River flow together to the Atlantic Ocean forming a common canal known as Padre Santo Canal belonging to the Ria de Huelva.

Three sampling sites were selected in this area of the southwest coastal of Spain (Fig. 1). The first one was located near Odiel River mouth in front of the factory Atlantic Copper $\left(3^{\circ} 13.5^{\prime} \mathrm{N} 6^{\circ} 57.2^{\prime} \mathrm{W}\right)$; the second sampling site was located near Tinto River mouth in front of the dock of La Rábida near phosphogypsum deposits $\left(37^{\circ} 12.5^{\prime} \mathrm{N} 6^{\circ} 56^{\prime} \mathrm{W}\right)$; and the last sampling site was located at Palos's industrial park in front of the Cepsa oil refinery of the Rábida (Huelva) $\left(37^{\circ} 09.9^{\prime} \mathrm{N} 6^{\circ} 54.8^{\prime} \mathrm{W}\right)$, in the common canal of Odiel and Tinto River, Padre Santo Canal.

Four samplings were realized from October 2004 to May 2006, two of them were realized at autumn (October 2004 and October 2005) and the others were realized at spring (April 2005 and May 2006).

\subsection{Fish collection}

Specimens of Senegal sole were collected at each sampling site for each sampling period and were transported in aerated tanks to Mazagon's port (Huelva). A total of 97 (125.04 $\pm 27.12 \mathrm{~g}$ Weight, $23.14 \pm 1.8 \mathrm{~cm}$ Length) fish were decapitating, dissected and sam-

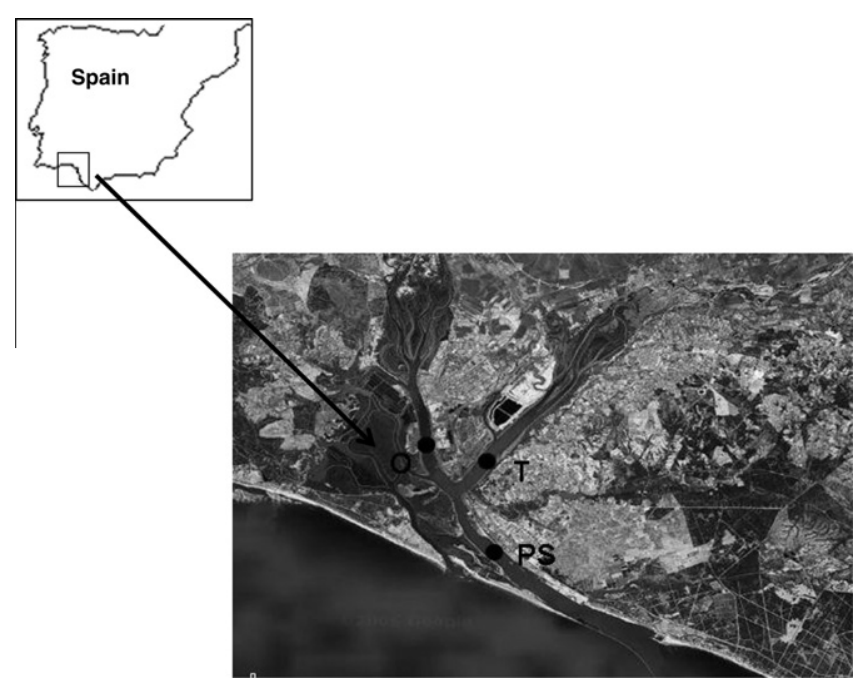

Fig. 1. Location map of sampling sites in Huelva Estuary (Spain): O (Odiel river); $T$ (Tinto river); PS (Padre Santo Canal).

ples of muscle of each fish were taken. Fish tissues were transported to the laboratory in liquid nitrogen and stored at $-80^{\circ} \mathrm{C}$. Twelve specimens of $S$. senegalensis $(182.52 \pm 23.89 \mathrm{~g}$ Weight, $25.27 \pm 0.78 \mathrm{~cm}$ Length) were used as control fish, since they were obtained from the aquaculture facilities of the Faculty of Marine and Environmental Sciences (University of Cadiz, Spain).

\subsection{Selection of chemical parameters}

In the studied estuary, the Tinto and Odiel rivers drain the central and eastern part of the Iberian Pyrite Belt (IPB), one of the most famous sulphide mining regions in the world, with a predominantly $\mathrm{Zn}-\mathrm{Cu}-\mathrm{Pb}$ mineralization. Sulphides are stables and very insoluble in redox condition, but mining activity exposes the minerals to atmospheric condition, then sulphide oxidation takes place generating acidity, sulphates and liberating Fe and accessory metals and metalloids (Cánovas et al., 2007).

Furthermore, in the 1960s a large chemical industry area was installed in the Ría de Huelva with industrial discharges into the estuary of sulphuric acid, sulphates and heavy metals aggravating the pollution problem in the estuary. Although these metals tend to occur at very low levels in the environment, anthropogenic activities as main cause of metal release into the environment can be pointed out (Vicente-Martorell et al., 2009). Thus, significant amounts of arsenic in the Tinto and Odiel rivers and the estuarine waters have been found (Sarmiento et al., 2009).

Taking account these natural and anthropogenic influences over the Huelva estuary, two metal groups have been considered in this research. The first group of metals with a well-known biological activity in organisms (essential metals) included $\mathrm{Fe}, \mathrm{Zn}$ and $\mathrm{Cu}$. Their influences on metabolic routes as well as other processes make most of them necessary for life, being their distributions in tissues based on factors related to fish biology and their levels regulated according to their physiological activity. They are necessary for life, but an excess may also represent a serious risk.

The second group of two metals (non-essential) included significant metal in the area such as $\mathrm{Cd}$, As and $\mathrm{Pb}$. They are considered as non-necessary or toxic even at low levels in organisms. The bioaccumulation patterns of non-essential metals may express easily the trends to accumulation of metals with no biological activity and point out the anthropogenic influence in the fish environment.

On the other hand, 16 PAHs identified by United States Environmental Protection Agency (USEPA) and World Health Organisation 
(WHO) as priority pollutants have been analysed in samples of sediment. The 16 PAHs (total PAHs-TPAHs) have been divided in two different categories: low molecular weight PAHs-LPAHs (naphthalene, acenaphthylene, acenaphthene, fluorene, phenantherene, anthracene, fluoranthene and pyrene) and high molecular weight PAHs-HPAHs (benzo(a)anthracene, chrysene, benzo(b)fluoranthene, benzo(k)fluoranthene, benzo(a)pyrene, dibenzo(a,h)anthracene, benzo(g,h,i)perylene, indeno(1,2,3-cd)pyrene).

\subsection{Heavy metals analysis in fish}

Collected fishes were dissected and samples from muscle were taken. Freeze-dried muscle samples $(0.2 \mathrm{~g})$ were digested with $7 \mathrm{~mL} \mathrm{HNO}_{3} 65 \%$ by microwave heating. After microwave digestion, samples were diluted up to $25 \mathrm{~mL}$ with Milli-Q deionised water. Metal concentrations of digested tissue samples were analysed by ICP-MS and ICP-AES. The accuracy of methodology applied was satisfactory evaluated using DORM-2 (dogfish muscle) certified reference materials.

\subsection{Heavy metals analysis in sediments}

Surface sediment samples $(2-20 \mathrm{~cm})$ were collected using a grab, stored in polyethylene bags at $-4{ }^{\circ} \mathrm{C}$ for a few days (3-5 days) and dried at $105^{\circ} \mathrm{C}$ during $24 \mathrm{~h}$, grinded using an agate mortar, sieved through a stainless steel mesh in order to obtain fine particle-size fractions and stored in polyethylene bottles until analysis. The BCR sequential extraction (exchangeable, reducible, oxidisable and residue fraction) procedure was applied to fine particle-size fractions (Davidson et al., 1999) and speciation and total concentrations of metal were evaluated by using ICP-AES or AAS. NIST 1649a certified reference estuarine sediment was used for analysis validation.

\subsection{Heavy metals analysis in water}

Samples collection was carried out using a peristaltic bomb and no filtered and filtered samples were obtained in situ by using $0.45 \mu \mathrm{m}$ Calyx Capsule MSI filter connected on line when required. Total metal, particulate metal fraction and dissolved metal fractions (labile organic, labile inorganic, moderately labile inorganic, moderately labile organic and no labile dissolved metal) were analysed by stripping voltammetry after acid digestion. Dissolved metal speciation was carried out by metal fractionation to different $\mathrm{pH}$ distinguished among labile inorganic and organic metal, moderately labile inorganic and organic metal and inert fraction. In addition, particulate and organic and inorganic dissolved arsenic species were evaluated by using hydride generation and AAS, with an operational discrimination among fractions. Analytical methods were checked by using CRM 505 certified reference estuarine water.

\subsection{Analytical procedure for PAHs}

PAH analysis in sediment was based on the analytical procedure proposed by the USEPA $(1996,2000)$. Two to four grams of sediment was treated with anhydrous $\mathrm{Na}_{2} \mathrm{SO}_{4}$. The samples were Soxhlet-extracted with $100 \mathrm{~mL}$ dichloromethane-acetone $(8: 2 \mathrm{v} /$ v) for $24 \mathrm{~h}$ (6 cycles per hour). The extracts were purified on florisil columns, and the PAHs were eluted with $100 \mathrm{~mL}$ dichloromethane-hexane $(2: 8 \mathrm{v} / \mathrm{v})$. The extract was concentrated to $1 \mathrm{~mL}$ using a rotary evaporator after changing the solvent from dichloromethane-hexane to acetonitrile. $\mathrm{Na}_{2} \mathrm{SO}_{4}$ was of analytical grade and dichoromethane, hexane, acetone and acetonitrile were HPLC grade.
The composition and concentration of 16 different PAHs was determined by HPLC. A standard solution, SUPELCO 47940-u PAH mix in acetonitrile (containing 16 individual PAHs), was used for quantification.

\subsection{Fixed wavelength fluorescence measurements (FF)}

Post-mitochondrial supernatant (PMS) of muscle were further diluted in methanol $50 \%$ to 1:400 for FF measurement. Fluorescent readings were performed for naphthalene-type metabolites at excitation/emission 290/335 nm, benzo(a)pyrene-type metabolites readings were made at $380 / 430 \mathrm{~nm}$, for pyrene-type metabolites readings were made at $341 / 383$ and for phenanthrene-type metabolites readings were made at 256/380. Muscle cytosol metabolites are reported on the basis of milligram protein as previously adapted by Gagnon and Holdway (2000).

\subsection{Enzymes analysis}

Just before enzymatic analysis, a portion of the dorsal muscle (0.1-0.2 g) was homogenized (Ystral GmbH d-7801 Dottingen homogenizer) in $1 \mathrm{ml}$ of ice-cold phosphate buffer ( $\mathrm{pH} 7.2,0.1 \mathrm{M})$ and centrifuged at $3300 \mathrm{~g}$ for $3 \mathrm{~min}$ at $4{ }^{\circ} \mathrm{C}$. Muscle supernatants were used to measure AChE by the Ellman's technique (Ellman et al., 1961) adapted to microplate (Guilhermino et al., 1996). Briefly, $0.25 \mathrm{ml}$ of the reaction solution [ $30 \mathrm{ml}$ of phosphate buffer, $1 \mathrm{ml}$ of the reagent dithiobisnitrobenzoate (DTNB) $10 \mathrm{mM}$ (acid dithiobisnitrobenzoate and sodium hydrogen carbonate in phosphate buffer) and $0.2 \mathrm{ml}$ of acetylcholine iodide $0.075 \mathrm{M}$ ] was added to $0.05 \mathrm{ml}$ of the supernatant of fish muscle homogenate with protein concentrations of $0.5 \mathrm{mg} \mathrm{ml}^{-1}$ in a 96 well microplate. The optical density was measured at $412 \mathrm{~nm}$ in a microplate reader (Bio Tek Power Wave 340) during $5 \mathrm{~min}$ at $25^{\circ} \mathrm{C}$. Acetylthiocholine was used as substrate in all the assays. Two other portions of the dorsal muscle (0.1-0.2 g) were used to analyse LDH and IDH activities, respectively. For LDH determinations, samples were homogeneized in $1 \mathrm{ml}$ of ice-cold Tris/ $\mathrm{NaCl}$ buffer ( $\mathrm{pH} 7.2$, Tris $81.3 \mathrm{mM}$; $\mathrm{NaCl} 203.3 \mathrm{mM}$ ) and centrifuged at $3300 \mathrm{~g}$ for $3 \mathrm{~min}$ at $4{ }^{\circ} \mathrm{C}$ after three frozen/unfrozen cycles. LDH activity was determined by measuring the amount of pyruvate consumed due to NADH oxidation at $340 \mathrm{~nm}$ according to Vassault (1983) adapted to microplate (Diamantino et al., 2001). Briefly, $0.25 \mathrm{ml}$ of $0.25 \mathrm{mM}$ NADH solution in Tris/ $\mathrm{NaCl}$ buffer and $0.04 \mathrm{ml}$ of $12 \mathrm{mM}$ pyruvate solution in Tris/ $\mathrm{NaCl}$ buffer were added to $0.01 \mathrm{ml}$ of muscle homogenate supernatant with $1 \mathrm{mg} \mathrm{ml}^{-1}$ protein concentration (four replicates per sample). The enzymatic activity was then determined at $340 \mathrm{~nm}$ in a Bio Tek Power Wave 340 microplate reader during $2.5 \mathrm{~min}$ at $25^{\circ} \mathrm{C}$. For IDH activity, samples were homogenized in Tris (hydroxymethyl)-aminomethane buffer ( $\mathrm{pH} 7.8,50 \mathrm{mM}$ ), followed by centrifugation at $3300 \mathrm{~g}$ for $3 \mathrm{~min}$ at $4{ }^{\circ} \mathrm{C}$. IDH activity was determined by the increase in NADPH at $340 \mathrm{~nm}$, according to Ellis and Goldberg (1971) adapted to microplate (Lima et al., 2007). Briefly, $0.2 \mathrm{ml}$ of the reaction solution containing $40 \mathrm{ml}$ of Tris buffer, $15 \mathrm{ml}$ of $2 \mathrm{mM}$ Manganese (II) chloride and $15 \mathrm{ml}$ of $7 \mathrm{mM}$ DL-isocitric acid in ultrapure water was added to $0.05 \mathrm{ml}$ of muscle homogenate supernatant with $1 \mathrm{mg} \mathrm{ml}^{-1}$ protein concentration (four replicates per sample) plus $0.05 \mathrm{ml}$ of $0.5 \mathrm{mM}$ $\mathrm{NADP}^{+}$. The enzymatic activity was determined at $340 \mathrm{~nm}$ in a Bio Tek Power Wave 340 microplate reader during $3 \mathrm{~min}$ at $25^{\circ} \mathrm{C}$.

\subsection{Statistical analysis}

A total of 97 samples were included in the analyses; 43 samples representing Odiel River (24 samples for autumn and 19 samples for spring season), 34 samples representing Tinto River (16 sam- 
ples for autumn and 18 samples for spring season) and 20 samples representing Padre Santo Canal for autumn season.

Statistical analyses were performed using the statistical software package STATISTICA (data analysis software system) version 7 (2004, Statsoft, Inc., USA).

For each data set, the assumptions of an analysis of variance (ANOVA), normality and equal variance, were checked using Shapiro-Wilks and Levene tests, respectively. If data set met assumptions, one-way ANOVA were conducted and where significant, a post-hoc mean comparison test (Tukey's test) was realized. If data set not met assumptions, the Kruskal-Wallis and Mann Whitney (one-tail) tests to found the significant differences was conducted. To analyse the correlation between biomarkers and heavy metals, Pearson and Spearman correlations test were used. All statistical analyses were conducted at an alpha level of 0.05 .

\section{Results}

\subsection{Heavy metals concentrations in water, sediment and muscle}

$\mathrm{As}, \mathrm{Cd}, \mathrm{Cu}, \mathrm{Pb}$ and $\mathrm{Zn}$ were studied as metallic pollutants in Huelva estuary. They were analysed in water, sediment and muscle samples. The study was completed with the Fe analysis in benthic samples of sediment and sole muscle. It is considered a nonhazardous metal and shows higher concentrations than other trace metals, but may be important in the biomarkers activities. Thus, it was analysed in fish tissue and the speciation of Fe in sediment was done by BCR method in order to study possible correlations with biological parameters.

Total metal concentrations in water samples evaluated in each sampling sites are shown in Table 1 . They can be arranged as follows (highest content to lowest content): $\mathrm{Zn}>\mathrm{Cu}>\mathrm{Pb} \approx \mathrm{As}>\mathrm{Cd}$. The ANOVA analysis showed significant seasonal variability for $\mathrm{Cd}$ and $\mathrm{Cu}$ levels in water $(p<0.05)$ with higher values during spring. Generally, content of metal in Tinto and Odiel sites were higher than content of metal in the Padre Santo Canal site although no significant differences were found among sampling sites. No significant differences were also found for year sampling.

In relation to speciation in water, metals were arranged by higher percentages of dissolved concentration (related with more availability than particulate metal): As $>\mathrm{Cd}>\mathrm{Zn}>\mathrm{Pb}>\mathrm{Cu}$. The seasonal variability found for dissolved metal $(p<0.05)$ was due to the decrease of this fraction for $\mathrm{Zn}, \mathrm{Cd}$ and $\mathrm{Pb}$ in autumn samples.

The different fractions obtained from dissolved metals showed $\mathrm{Pb}$ with the highest percentage of no labile concentration, $\mathrm{Cd}$ mostly associated with the labile inorganic fraction and As presented as inorganic metal.

The total metal concentrations in sediments for each sampling site of Ría de Huelva are shown in Table 1. The high values for all metals were obtained for sampling of 2005, especially for Cd and $\mathrm{Pb}$ during autumn, coinciding with a period of low rainfalls. Allowing to arrange the metals from higher to lower mean content in this estuary as: $\mathrm{Cu}>\mathrm{Zn}>\mathrm{Pb}>\mathrm{As}>\mathrm{Cd}$. It is noteworthy that metals with higher percentages of particulate fraction $(\mathrm{Cu}, \mathrm{Pb}$ and $\mathrm{Zn})$ showed higher contents in sediment. ANOVA analysis did not show significant seasonal and spatial variability at $p<0.05$.

The distribution of heavy metals fractions using BCR method (Vicente-Martorell et al., 2009) showed Zn and Cd mainly bound to weak acid and carbonates being more available. In the case of $\mathrm{Cu}$ appeared mainly associated to oxidisable fraction, although reducible and exchangeable fractions were important too. $\mathrm{Pb}$ was associated to reducible, oxidisable and residual fractions and fraction of this metal bound to weak acid was not observed. As was the least available metal studied, appearing mainly associated to residual fraction. Based on these results, metals in sediments of Huelva estuary can be arranged from more available to less available as follows: $\mathrm{Cd}>\mathrm{Zn}>\mathrm{Cu}>\mathrm{Pb}>$ As. Significant differences were not found between sampling sites and seasons for metal speciation by ANOVA analysis.

Concentration of heavy metals in muscle (Fig. 2) showed the following accumulation ranking: $\mathrm{Zn}>\mathrm{As}>\mathrm{Cu}>\mathrm{Pb}>\mathrm{Cd}$. By using non parametric Kruskal-Wallis analysis significant differences among sampling sites were not found. However significant variations of $\mathrm{Cu}$ concentration were found in muscle for season $\left(F_{(1,85) \quad(p<0.05)}=42.807\right)$ founding higher level in spring than in autumn.

\subsection{PAHs concentrations in sediments}

The average concentration of TPAH in each sampling site is $1.51 \mathrm{mg} / \mathrm{kg}$ d.w. in Odiel River, $1.64 \mathrm{mg} / \mathrm{kg}$ d.w. in Tinto River and $2.45 \mathrm{mg} / \mathrm{kg}$ d.w. in Padre Santo Canal. In Odiel River, Tinto River and Padre Santo Canal were detected 15, 10 and 11 of total 16 analysed PAHs, respectively.

Nine of the 16 analysed PAHs appeared in all sediment samples: naphthalene, acenaphthene, fluorene, phenanthrene, anthracene, fluoranthene, pyrene, chrysene and dibenzo(a,h)anthracene. On the other hand, benzo(a)anthracene only appeared in Odiel and Tinto River sediments and benzo(b)fluoranthene only appeared in Odiel and Padre Santo Canal sediments. Finally, PAHs with a lower frequency (present only in Odiel River) were benzo(k)fluoranthene, benzo(a)pyrene, benzo(g,h,i)perylene and indene $(1,2,3$ cd)pyrene.

Table 1

Total metal concentrations in sediments and water. Sampling sites: (1) Odiel River; (2) Tinto River; (3) Padre Santo Canal.

\begin{tabular}{|c|c|c|c|c|c|c|c|c|c|c|c|c|}
\hline \multirow[t]{2}{*}{ Date } & \multirow[t]{2}{*}{ Station } & \multicolumn{6}{|c|}{ Sediments $\left(\mathrm{mg} \mathrm{kg}^{-1}\right)$} & \multicolumn{5}{|c|}{ Water $\left(\mu \mathrm{g} \mathrm{L}^{-1}\right)$} \\
\hline & & $\mathrm{Zn}$ & $\mathrm{Cd}$ & $\mathrm{Pb}$ & $\mathrm{Cu}$ & As & $\mathrm{Fe}$ & $\mathrm{Zn}$ & $\mathrm{Cd}$ & $\mathrm{Pb}$ & $\mathrm{Cu}$ & As \\
\hline \multirow[t]{3}{*}{ October 2004} & 1 & 602.94 & 3.43 & 136.76 & 1115.70 & 85.15 & 44689,423 & 80.6 & 1.3 & 3.7 & 34.5 & 4.7 \\
\hline & 2 & 1506.68 & 4.84 & 246.15 & 2099.49 & 198.79 & 84244,363 & 324.8 & 1.3 & 5.7 & 37.1 & 3.0 \\
\hline & 3 & 1327.12 & 3.87 & 343.25 & 2325.75 & 237.74 & 75822,717 & 121.5 & 0.8 & 2.6 & 20.9 & 2.8 \\
\hline \multirow[t]{3}{*}{ April 2005} & 1 & 1736.95 & 33.20 & 1166.67 & 3333.63 & 615.43 & 85647,318 & 191.2 & 3.1 & 6.1 & 57.2 & 4.1 \\
\hline & 2 & 738.41 & 5.11 & 358.38 & 1470.11 & 284.29 & 70159,777 & 198.3 & 4.5 & 7.4 & 68.0 & 6.0 \\
\hline & 3 & 1489.18 & 8.93 & 879.06 & 2469.38 & 599.81 & 71947,573 & 52.8 & 0.8 & 5.2 & 27.8 & 3.2 \\
\hline \multirow[t]{3}{*}{ October 2005} & 1 & 1308.01 & 15.99 & 817.35 & 2157.68 & 375.03 & 67720,910 & 124.9 & 1.6 & 17.8 & 56.7 & 9.3 \\
\hline & 2 & 1161.15 & 18.30 & 974.95 & 1513.77 & 530.39 & 189673,495 & 119.8 & 2.2 & 3.5 & 47.3 & 7.5 \\
\hline & 3 & 1569.12 & 14.04 & 1028.15 & 2652.79 & 486.77 & 55312,813 & 49.8 & 0.7 & 5.7 & 22.2 & 6.2 \\
\hline \multirow[t]{3}{*}{ May 2006} & 1 & 966.92 & 5.08 & 238.87 & 1829.17 & 246.24 & 59015,014 & 381.6 & 8.9 & 6.2 & 54.7 & 2.9 \\
\hline & 2 & 1054.66 & 5.41 & 404.33 & 2505.34 & 343.86 & 74340,571 & 252.0 & 6.8 & 5.0 & 72.4 & 5.3 \\
\hline & 3 & 1337.25 & 1.50 & 269.64 & 1412.51 & 211.98 & 61426,782 & 108.7 & 1.7 & 6.2 & 57.7 & 2.6 \\
\hline
\end{tabular}


As

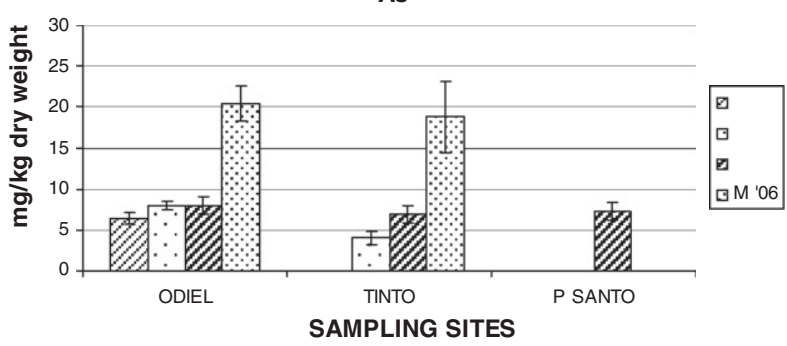

Cd

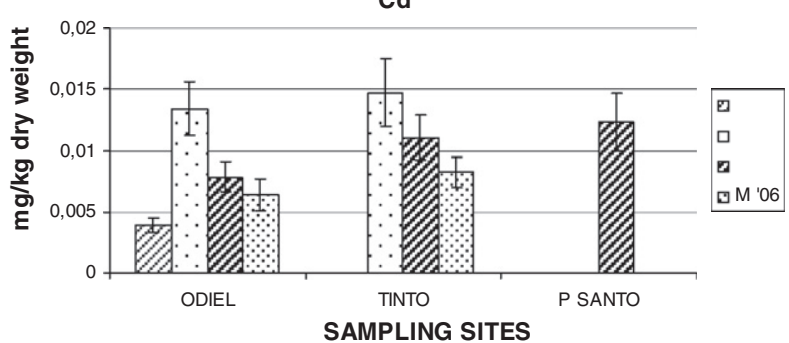

$\mathrm{Fe}$

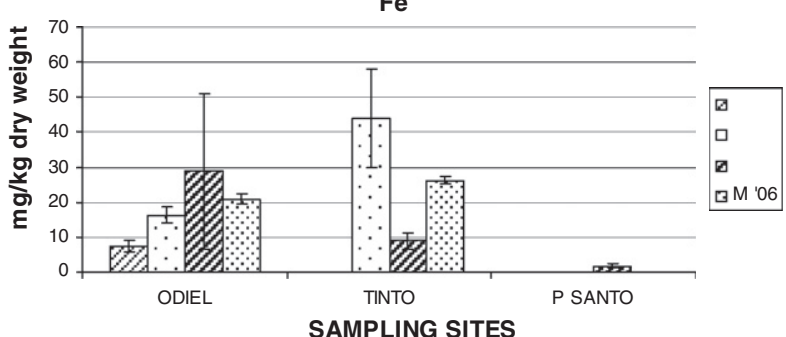

$\mathrm{Pb}$

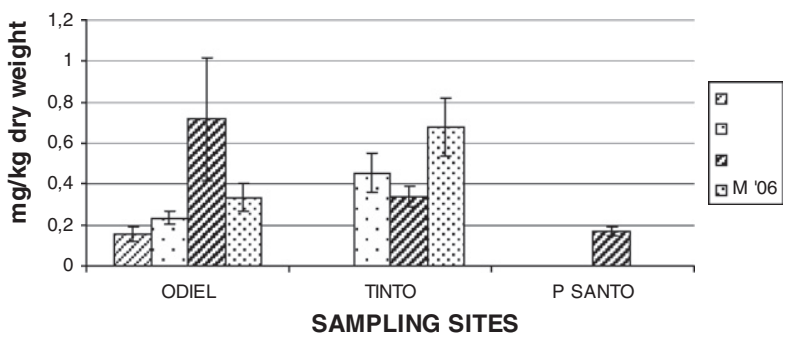

Cu

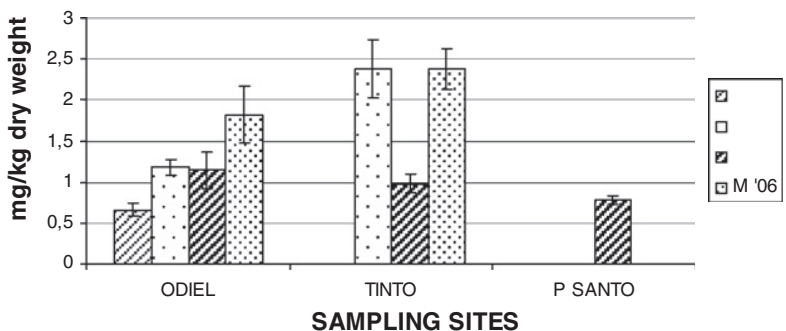

$\mathrm{Zn}$

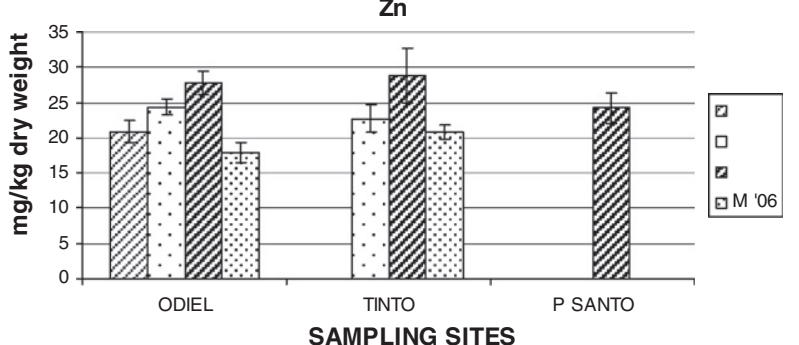

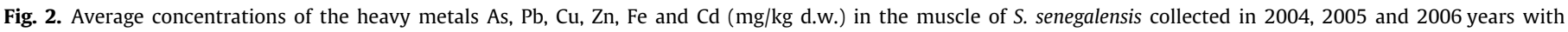
corresponding SE bars. (O: october, A: april, M: may).

In relation to relative frequency of analyzed PAHs in the different sampling sites, only a few of them were majority conforming around $75 \%$ of TPAHs in the sediment: naphthalene, fluorine and dibenzo(a,h)anthracene.

To establish the main source of PAHs several indexes have been proposed by different authors. These indexes are based on the composition and distribution of PAHs in function of the emission source (Yang, 2000).

The index selected to determinate the PAHs source in the different sampling sites is the relation between low and high molecular weight PAHs present in each sediment sample (De Luca et al., 2005).

The majority of sampling sites showed a petrogenic origin. Despite the Padre Santo Canal with a relation LPAHs/HPAHs around 3. This sampling site is located in front to loading and unloading zone of "La Rábida" oil refinery. In the case of Tinto River, the petrogenic origin could be due to Huelva Nautical Club located in the sampling site with the presence of many vessels in the zone. Respect to the Odiel River, the index value next to one does not allow revealing the main origin of PAHs.
The higher concentration of PAHs (LPAHs) was observed in the sediment of Padre Santo Canal (Table 2), this is the sampling site more polluted by PAHs of the Huelva estuary. Roy et al. (2003) observed higher PAHs of low molecular weight in coal oil point (COP) sediments than high molecular PAHs. This is consistent with previous studies showing that natural petroleum seeps lend to have higher concentrations of lower molecular weight aromatic hydrocarbons (Spies et al., 1980).

\subsection{PAH type metabolites in muscle}

Pyrene-type metabolites showed the highest concentrations in muscle (Fig. 3). The preferential accumulation of PAHs is determined by their solubility and bioavailability, related to the octanol-water partition coefficient (K08), molecular weight, exposure route and incorporation of the PAHs which involves the habits of native biota (Conell and Miller, 1984). Schrap and Opperhuizen (1990) revealed that PAHs with high (K08) values, such as pyrene and benzo[a]pyrene, bind to humic dissolved material or to other dissolved organic material present more than PAHs with low K08

Table 2

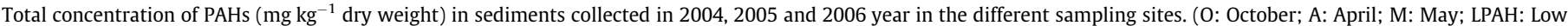
Molecular Weight PAH; HPAH: High Molecular Weight PAH; TPAH: Total PAH).

\begin{tabular}{|c|c|c|c|c|c|c|c|c|c|c|c|c|}
\hline & \multicolumn{4}{|l|}{ Odiel } & \multicolumn{4}{|l|}{ Tinto } & \multicolumn{4}{|c|}{ Padre Santo Canal } \\
\hline & O ‘04 & A ‘05 & O ‘05 & M ‘06 & O ‘04 & A ‘05 & O ‘05 & M ‘06 & O ‘04 & A ‘05 & O ‘05 & M ‘06 \\
\hline LPAH & 0.51 & 0.97 & 0.94 & 0.96 & 0.87 & 0.67 & 1.12 & 1.36 & 1.42 & 1.07 & 0.16 & 4.62 \\
\hline НРAH & 0.50 & 0.22 & 1.18 & 0.75 & 0.61 & 0.41 & 0.52 & 1.00 & 1.47 & 0.54 & 0.10 & 0.32 \\
\hline ТРAH & 1.01 & 1.19 & 2.13 & 1.72 & 1.48 & 1.09 & 1.64 & 2.36 & 2.89 & 1.61 & 0.27 & 4.95 \\
\hline
\end{tabular}



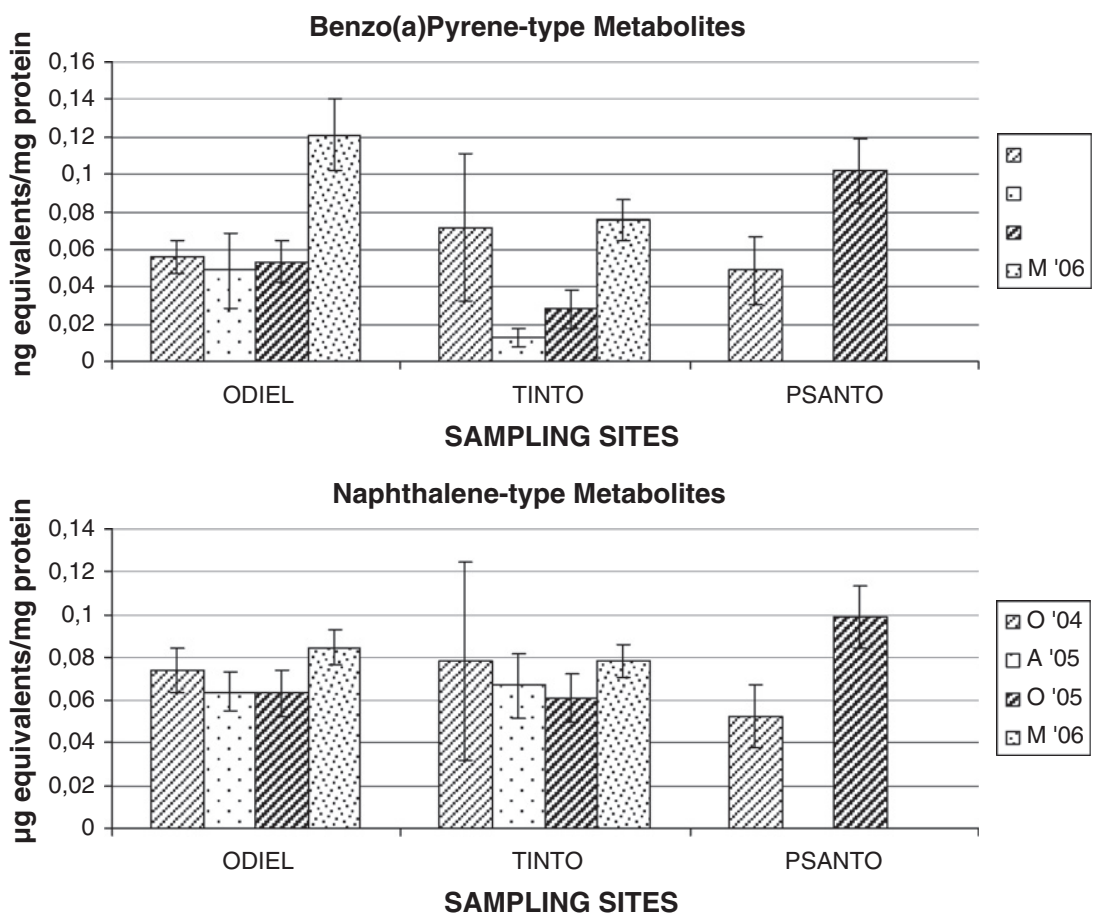

Pyrene-type Metabolites

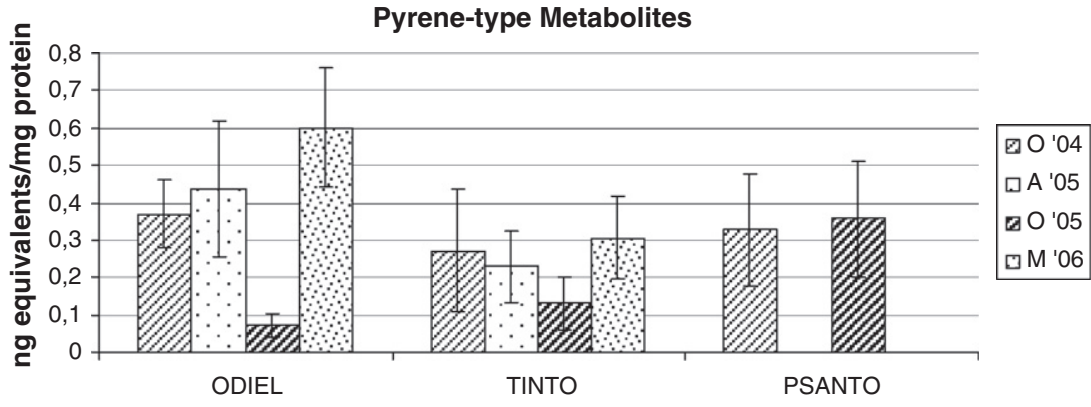

SAMPLING SITES

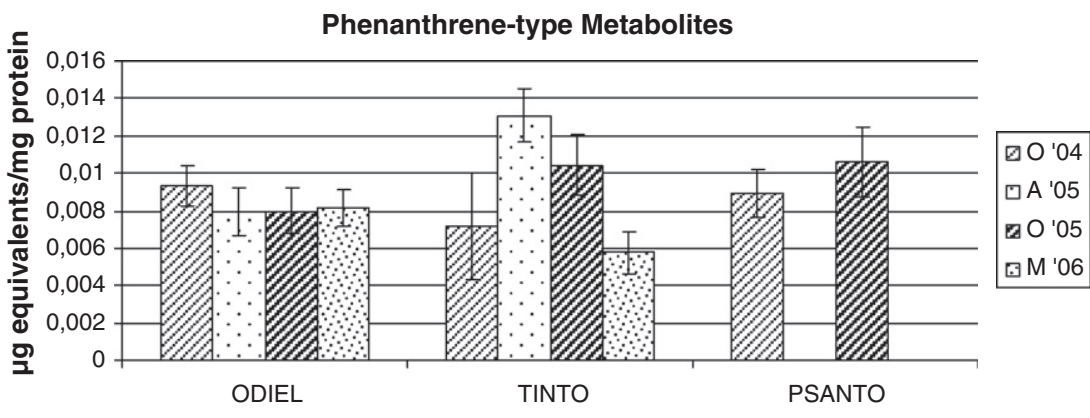

Fig. 3. PAHs metabolites (average and standard error) in muscle of S. senegalensis captured from the different sampling sites in 2004, 2005 and 2006 year. (O: october, A: april, M: may).

values (anthracene or phenanthrene). When the rate of desorption from particles and humic material is rapid, uptake from interstitial water seems to prevail as for LPAHs; when the desorption rate is slow compared with the ingestion rate, then ingestion becomes more competitive as for HPAHs (Narbonne et al., 1999).

\subsection{Biomarkers}

AChE and IDH activities were significantly different in fish from Tinto and Odiel River compared to the control group. These differ- ences were observed mainly in spring season (Fig. 4). No differences were observed in LDH activity.

\subsubsection{AChE correlationships}

AChE activity showed a significant correlation with the reducible fraction of Fe in sediment ( $p=0.048, r=-0.636$ ).

Correlationships between some heavy metals in water and AChE were also established: dissolved fraction of $\mathrm{Pb}(p=0.033$, $r=-0.673)$; few labile inorganic fraction of $\mathrm{Cd}(p=0.000$, 

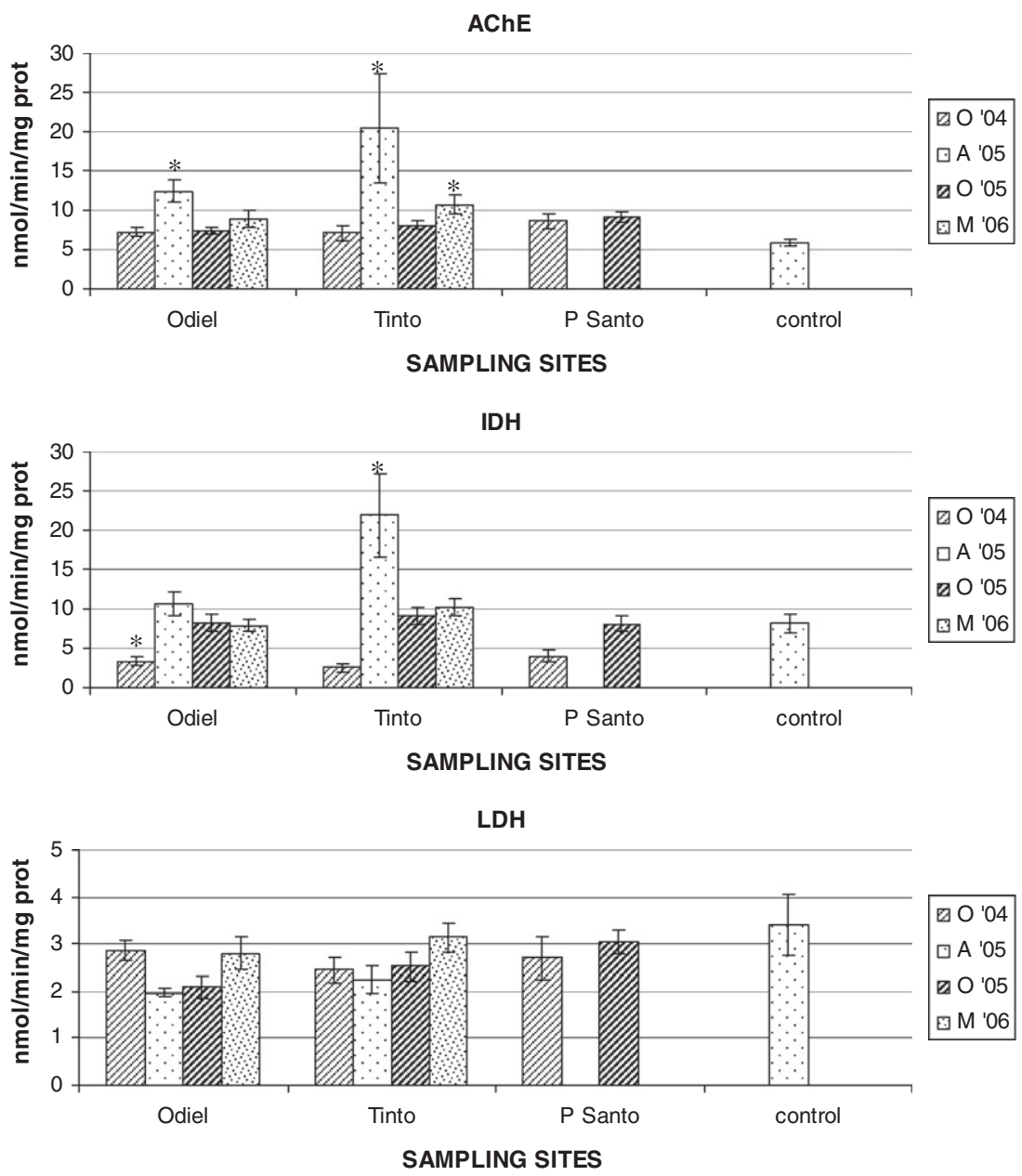

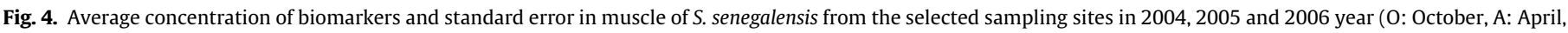
M: May). Asterisks denote means are significantly different from the control $(p<0.05)$.

$r=0.894)$; no labile fraction of $\mathrm{Cd}(p=0.016, r=-0.732)$ and few labile organic fraction of $\mathrm{Cu}(p=0.029, r=0.685)$.

No significant correlations were observed between AChE activity and heavy metals in muscle of $S$. senegalensis and neither for PAHs and this enzyme.

\subsubsection{IDH correlationships}

IDH activity showed significant correlations with different fractions of heavy metals in sediment: residue fraction $(p=0.048$, $r=0.636)$ and total concentration of As $(p=0.019, r=0.721)$; total concentration of $\mathrm{Pb}(p=0.048, r=0.648)$ and total concentration of Cd $(p=0,022, r=0.709)$.

Correlationships between some heavy metals in water and IDH were also established: labile inorganic fraction $(p=0.038$, $r=0.661)$ and dissolved fraction of $C d(p=0.033 ; r=0.672)$ and few labile fraction $(p=0.000, r=0.903)$, total concentration $(p=0.009, r=0.770)$ and dissolved fraction of $\mathrm{Cu}(p=0.013$; $r=0.745)$.

No significant correlations were observed between IDH activity and heavy metals in muscle of $S$. senegalensis. One correlation was established between IDH and PAHs concentration in sediments, specifically with benzo(b)fluoranthene concentration $(p=0.002$, $r=-0.847)$.

\subsection{3. $\mathrm{LDH}$ correlationships}

Correlations were observed between LDH activity in muscle of $S$. senegalensis and interchangeable fraction of $\mathrm{Cd}$ in sediment $(p=0.022, r=-0.709)$ and particulate fraction of As $(p=0.005$, $r=-0.806)$ and labile inorganic fraction of $\mathrm{Zn}(p=0.025$; $r=-0.697)$ in water. No significant correlations were observed between LDH activity and heavy metals in muscle and neither for PAHs and this enzyme.

\section{Discussion}

To establish the contamination grade for PAHs in the different sampling sites, the level of PAHs observed was compared with the Holand Environmental Quality Criteria to Marine Sediments (Kamer, 1994).

This criteria is established in basis to the summatory of 10 PAHs (naphthalene, phenanthrene, anthracene, fluoranthene, chrysene, benzo(a)anthracene, benzo(k)fluoranthene, benzo(a)pyrene, benzo(ghi)perylene and indene. The summatory of those PAHs in Odiel River was $0.68 \mathrm{mg} / \mathrm{kg}, 0.82 \mathrm{mg} / \mathrm{kg}$ in the Tinto River and $1.81 \mathrm{mg} /$ $\mathrm{kg}$ dry weight in Padre Santo Canal. According to this criteria, Odiel and Tinto River were classified as no or few contaminated sites and Padre Santo Canal was classified as moderately contaminated site where a high concentration of LPAHs was observed in the sediment. Biomarkers analysed in this work showed no correlations with PAHs concentrations in sediment or PAH-type metabolites analysed in muscle.

The mechanism of inhibition of AChE by PAHs is unknown and contradictory effects of PAHs on this enzyme and on cholinesterases 
in general may be found in the literature. For example, exposure of Astyanax sp. to petroleum WSF (Water Soluble Fraction) resulted in a decrease in muscle AChE activity (Akaishi et al., 2004). GoldBouchot et al. (2006) observed an AChE inhibition in Nile tilapia (Oreochromis niloticus) following benzo(a)pyrene (BaP) exposure and Vieira et al. (2008) also observed a inhibition of AChE in Pomatochistus microps exposed to anthracene, BaP and WAF (Water Accommodation Fraction of oils). On the other hand, Jifa et al. (2006) reported that AChE in the Japanese sea bass (Lateolabrax japonicus) after exposure to BaP was not affected. Solé et al. (2008) found no AChE inhibition in juveniles sole ( $S$. senegalensis) exposed to the WAF of the "Prestige" fuel oil and Bonacci et al. (2009) also observed a lack of concentration-response of AChE activity and of significant effect of the highest PAH concentration in Adamussium colbecki. Silva et al. (2009) neither observed AChE inhibition although all the exposure groups showed the presence of PAHs. This absence of effects may be due to the low concentrations of the PAHs or the interaction of effects elicited by the many chemicals in the pollutant complex mixtures.

In relation to the LDH biomarker and PAHs, the literature is scarce. Authors such as Gravato et al. (2010) founded an inhibition of LDH activity in eels from an estuary contaminated with PAHs and Vieira et al. (2008) also observed the inhibition of LDH activity by water accommodated fractions of oils in Pomatochistus microps. On the other hand, Tintos et al. (2008) observed no significant effects in Oncorhynchus mykiss after exposure to BaP and Vieira et al. (2008) observed an increase of the LDH activity in P. microps exposed to BaP and anthracene. The response of LDH to PAHs seems to depend of mixture tested and thus, of its composition. The different effects also can be due to the presence of metals in the environment some of which have been found to inhibit the LDH activity of fish (Osman et al., 2007). Since different components of fuel oils may have opposite effects of LDH activity of fish, care should be taken when using this enzyme as a biomarker in sites contaminated with petrochemical products because the overall result may be "no effect" and this may lead to erroneous conclusions.

Only one correlationship was observed between biomarkers and PAHs concentrations: IDH activity and benzo(b)fluoranthene concentration in sediment. To discuss, in the present article, about IDH activity and PAHs is complicated. No references have been founded about IDH and PAHs pollution. In general, the literature in reference to IDH activity and pollution is scarce. Only two references, one of them on heavy metals (Napierska and Podolska, 2008), that will be discussed further on, and other on organophosphate pesticides (Almeida et al., 2010), where no effects on the IDH activity were observed, have been founded. However, in relation with benzo(b)fluoranthene, Nakata et al. (2003) calculated TCDD toxic equivalents (TEQs) for PCBs and PAHs in sediments and biota of the Ariake Sea (Japan) and PAHs occupied a considerable portion of (TEQs) in sediment (>97\%). Interestingly, benzo(b)fluoranthene was the dominant contributor to TEQ(PAH) in all species studied.

Lu et al. (2009) observed fish injected with benzo(b)fluoranthene appeared to be less active gradually and crouch in the corner of aquaria accompanying the exposure length extension. At last, the fish showed no response at the change of surrounding.

The lack of susceptibility to major of PAHs in this study indicates that more research would be worthwhile.

In relation to the heavy metals concentrations in water, metal concentrations studied were considerably higher than background values and nature concentrations in water (Förstner and Wittmann, 1983; Azcue, 1993). Special attention should be care on dissolved $\mathrm{Cu}$ concentrations because their concentrations were higher (mean of five times) than those recommended by NOAA-EPA (USEPA, 2002). In addition, imperative values of regional government were exceeded in all sample sites except for first sampling, considering Tinto and Odiel point as limited area and Padre Santo
Canal as no limited area (in accordance with Andalusia Government instructions).

Concentrations of all metals studied in sediment were higher than guidelines values recommended by Canadian government (ISQG-PEL, 2001) in all samples collected. In the same sense that happened with dissolved $\mathrm{Cu}$ in water, special attention should be care on $\mathrm{Cu}$ concentrations because their concentrations were too much high.

The results obtained for muscle samples were compared with limit values and guidelines found in the bibliography (CEPA, 1996; EC, 2006; Demirak et al., 2006) using wet weights. The levels of metals in muscle were usually less than maximum levels and guidelines. However, several muscle tissues had higher concentrations of As than standard levels described in the literature. Otherwise, these results demonstrated the high risk for aquatic life due to the high metallic pollution and the high pollution degree in Odiel and Tinto River.

Interestingly, AChE and IDH activities in muscle of S. senegalensis present significative differences from the control group in Tinto and Odiel River, where the content of metal were higher than content of metal in the Padre Santo Canal although no significant differences were found among sampling sites.

In the present study correlationships were observed between ChEs activity and $\mathrm{Fe}$ (concentration in sediment) and $\mathrm{Cd}, \mathrm{Pb}$ and $\mathrm{Cu}$ (water concentrations). Is remarkable the importance of the chemical speciation of metals on its bioavailability and toxicity. Different fractions of the same metal showed different correlation patron with the AChE activity. For example, few labile inorganic fraction of Cd showed a positively correlation with the AChE activity but the no labile fraction of $\mathrm{Cd}$ showed a negative correlation. Moreover, metals concentrations analysed in water showed a major number of correlations with AChE with regard to the metals in sediment, indicating a higher toxicity of the dissolved fraction of the metals.

Negative correlations were observed between $\mathrm{Fe}, \mathrm{Cd}$ and $\mathrm{Pb}$ and AChE activity. Heavy metals are known to selectively inhibit AChE activity (De la Torre et al., 2002; Lionettto et al., 2003). The inhibition of cholinesterase enzymes in the nervous tissue and other targets organs is generally considered to be the critical effect leading to the acute toxicity of many toxic chemicals (Gill et al., 1990; Nagaraja and Desiraju, 1994; Liao et al., 2006). In aquatic organisms there is considerable diversity in the biochemical properties and distribution of $\mathrm{AChE}$ as well as in their sensitivity to anticholinesterase agents (Bocquené et al., 1990).

Generally, the toxicity of heavy metals is largely due to their reactions with sulfhydryl groups. Lipophilic organometallic compounds such as methylmercury and triethyltin easily cross the blood-brain barrier, whereas inorganic metallic compounds also reach the brain tissue (Bast, 1996). Bast (1996) also indicated that for many axonal toxins, deregulation of intracellular energy production is the main cause of toxicity.

Inhibition of AChE can result in excessive stimulation of cholinergic nerves, resulting in behavioural alterations such as tremors, convulsions, and erratic or lethargic swimming (Beauvais et al., 2001; Fernández-Vega et al., 2002; Almeida et al., 2010). However, exposure of fish metals causes different responses of AChE activity such as inhibition of (Lionettto et al., 2003), an increase in (Romani et al., 2003), or no change in (Beauvais et al., 2001) activity.

In concordance with our results, Pretto et al. (2010) also observed in white muscle of silver catfish an AChE activity increased after 7 days exposure to $0.414 \mathrm{mg} / \mathrm{L}^{-1}$ cadmium and Napierska and Podolska (2008) observed a negative impact of $\mathrm{Pb}$ on the cholinesterase activity in Platichthys flesus. Pb cations also inhibited AChE in muscle extracts of fathead minnows (Payne et al., 1996). Toxic effects in the tropical fish Hoplias malabaricus exposed in vivo to lead were reported by Rabito et al. (2005), where cholinesterase activity was inhibited in muscle after dietary doses of $\mathrm{Pb}$. 
The effect of $\mathrm{Cd}$ and $\mathrm{Pb}$ on ChEs is due to possible interference of metals with calcium mediated neurotransmitter release at neuromuscular junctions. In the brain $\mathrm{Cd}$ inhibits enzymes such as $\mathrm{Mg}^{2+}$-ATPase and $\mathrm{Na}^{+}-\mathrm{K}^{+}$-ATPase, causing metabolic effects and disrupting neurotransmitter uptake (Beauvais et al., 2001). According to Szavó et al. (1992) the catalytic properties of AChE can be inhibited by changes in the conformational structure of the enzyme secondary to metal-protein binding.

On the other hand, a positively correlation between $\mathrm{Cu}$ concentrations and AChE also were observed. Romani et al. (2003) observed an increase of AChE in muscle of Sparus auratus exposed to sublethal $(0.1-0.5 \mathrm{ppm})$ concentrations of copper. The results obtained lead the believe it probable that an increased Cu concentration in the aqueous medium gives, likely though the above-said interaction mechanism, a modulation in the catalytic activity of AChE forms, anyhow preserving their efficiency. Moreover, a possible AChE activation by $\mathrm{Cu}$ ions makes unlikely that the observed rise of enzyme activity in the extracts of brain and muscle of $S$. auratus may result from a de novo synthesis of other isoforms of AChE. Obviously, further and extensive studies about AChE expression are required to make a fitly clear this side of research.

In conclusion, organisms have several potential adaptations to changes in cholinesterases, such as increased synthesis and decreased synthesis of acetylcholine. The inhibition (negative correlations) and activation (positive correlations) of AChE activity in muscle reported in our study could be interpreted as changes in the enzyme due to binding metals with a functional active AChE site or other location such as the surface of the enzyme.

Effect of pollutants on IDH activity has been also analysed. Isocitrate dehydrogenase (IDH) participates in the tricarboxylic acid cycle, catalyzing the conversion of isocitrate to $\alpha$-ketoglutarate through oxidative decarboxylation and reducing oxidative NAD to be NADH, it is considered to be a rate-limiting enzyme in tricarboxylic acid cycle. Thus IDH activity has a tremendous influence on the organism's metabolism.

The IDH activity showed positive correlations with metals such as $\mathrm{Cd}$ and $\mathrm{Cu}$ concentrations in water and $\mathrm{As}, \mathrm{Pb}$ and $\mathrm{Cd}$ concentrations in sediment. Napierska and Podolska (2008) also observed a positive correlation between copper and IDH activity but no correlation was observed with cadmium. The positive effect of $\mathrm{Cu}$ on IDH activity can be explained by the fact that this enzyme is activated by metal cations.

On the other hand, Reddy et al. (2008) observed in Cyprinus carpio exposed to copper at different $\mathrm{pH}$ a progressive decrease in IDH activity from the day 1 of exposure. At pH 7.5 an increase in the activity of IDH at day 1 and 7 followed by their gradual decrease at day 15 and 30 and at pH 9.0 the IDH activity increased significantly at day 1 but the elevation gradually suppressed and reached to normal at day 30 . Increase in the ICDH activity at all the days of exposure suggests an elevation in oxidative metabolism; thereby the animal could derive more energy through it to meet the stress caused by the metal as well as alkaline $\mathrm{pH}$. Gradual decrease in the degree of elevation in the levels of energetic with the increase in exposure period indicates the adaptation of the fry to the toxic stress on prolonged exposure. So fish can tolerate and develop resistance to sublethal concentrations of copper in alkaline habitats as the fish could derive the necessary energy through the elevation of oxidative metabolism.

In relation to cadmium, Ivanina et al. (2008) studied the combined effects of cadmium (Cd) and temperature on key mitochondrial enzymes, including NAD- and NADP-dependent isocitrate dehydrogenases in Crassostrea virginica. NAPD-Isocitrate dehydrogenases were the most sensitive to $\mathrm{Cd}$ making Krebs cycle a likely candidate to explain Cd-induced impairment of mitochondrial substrate oxidation. Cd exposure also resulted in a decrease in activation energy of mitochondrial enzymes suggesting that mitochondria from Cd-exposed oysters could exhibit reduced capacity to respond to temperature rise with an adequate increase in the substrate flux. These interactive effects of Cd and temperature on mitochondrial enzymes could negatively affect metabolic performance of aquatic organisms in polluted environments during temperature increase such as expected during the global climate change and/or tidal or seasonal warming in estuarine and coastal waters.

Vaglio and Landriscina (1999) observed in liver of Sparus aurata exposed to cadmium, alterations in the activities of various liver enzymes. In mitochondria the activities of the NAD-isocitrate dehydrogenase increased by more than $20 \%$ after 3 days of cadmium administration. The increase in the activities of liver mitochondrial enzymes reported suggested that the cadmium intoxication response of $S$. aurata was strong stimulation of the terminal pathway of biological oxidation, probably due to alteration of mitochondrial membrane integrity, thus causing an effect similar to oxidative phosphorylation uncoupling with a consequent decreased ATP synthesis (Müller, 1986).

On the other hand, an inhibitory effect of cadmium on muscular IDH has been also reported in muscle of other organisms as pig and beef (Higashi et al., 1965; Toury et al., 1985).

Cadmium is a diverging element. In some cases, the effects increase with treatment duration, while elsewhere they are more serious at the beginning of treatment, followed by a tolerance or a restoration. Cadmium can produce a change of the cellular ultrastructure but sometimes the ultrastructure is unchanged.

In vitro subcellular fractions isolated from cadmium treated animals show both convergencies (lowering of mitochondrial ATPase and respiratory control, lowering of RNA and protein synthesis, and a diminution of myocardial contractility) and divergencies (substrate oxidation, electron transfer, and cadmium transport are either unchanged or diminished). Parallel studies of in vitro cadmium addition to subcellular fractions isolated from control animals, reveal an ambivalent action as well.

In all cases, cadmium has a greater effect in vitro than in vivo where cytosolic thionein renders the metal unavailable.

The diversity of dose, duration of treatment, mode of administration and the variety of tissues and organisms studied may explain these discrepancies (Toury et al., 1985).

In relation to arsenic, a lack of information about effects of this metal on IDH in fish has been observed. No information has been found about this metal and IDH activity in fish muscle, but some information have been found in other tissue/organisms. Unlike the effects observed in this work, arsenic is an effective inhibitor of mitochondrial pyruvate dehydrogenase and ketoglutarate dehydrogenase. This inhibition is mainly due to the reaction of arsenic with the vicinal thiol group of reduced lipoic acid. The decrease in pyruvate dehydrogenase activity leads to the decrease in the formation of acetyl CoA and subsequently isocitrate. The low availability of the substrate, isocitrate, may be the reason for a decrease in the activity of isocitrate dehydrogenase. On the other hand, the work realized by Shao et al. (2011) in wheat exposed to $\mathrm{As}, \mathrm{Cd}$ and $\mathrm{Pb}$ indicated different expression of IDH isoenzymes in leaves and roots of wheat. The expression levels of isoenzymes were different in response to the heavy metals. The I1 isoenzyme displayed no significant change with increasing concentrations of As. I5 band expression level was high at $25 \mathrm{mg} \mathrm{L}^{-1}$ of As, but higher than the control under $\mathrm{Cd}$ or $\mathrm{Pb}$ treatment, indicating that the expression of 15 isoenzyme band was induced variably in response to the treatment with $\mathrm{As}, \mathrm{Cd}$ or $\mathrm{Pb}$. On the other hand, $\mathrm{I} 3$ and $\mathrm{I} 4$ isoenzyme bands enhanced gradually with the increase in the concentrations of As. These tendency of changes described correlate largely with the results of respiration rates, establishing a link between the change in the respiration rate and the expression of IDH isoenzymes. It is therefore likely that heavy metals usually affect 
the respiration rate by influencing the expression of isoenzymes involved in respiratory mechanism. Isoenzyme profiles could be the reporters of a cell state at the molecular level of gene expression. Causes to increase of IDH activity with arsenic concentration in muscle fish deserve an in depth investigation.

Laszczyca (1989) studied activity of isocitrate (ICD) dehydrogenase in the mitochondrial fractions obtained from the soleus muscle (ST fibres), and from the superficial (FTb fibres) and deep (FTa fibres) parts of the gastrocnemius muscle of rats exposed to $\mathrm{Zn}$ and $\mathrm{Pb}$. Simultaneous action of zinc and lead produced an increase in ICD activity in FTb fibres but this response was not observed in other fibres or in the exposure with lead or zinc separately. These results suggest that the kind or muscular fibre is related with different susceptibility to metals and the mixer of metals can produce different responses than exposition of metals separately.

Other enzyme studied has been lactate dehydrogenase (LDH). LDH activity showed negative correlations with As and $\mathrm{Zn}$ concentrations in water and Cd concentration in sediment. LDH activity is measured as enzymatic markers of glycolytic capacity (Hammeren et al., 1992). Lavanya et al. (2011) observed a decrease on LDH activity in Catla catla exposed to arsenic. Bears et al. (2006) examined how arsenic species accumulate in $F$. heteroclitus liver interfered with stress-mediated gene expression of enzymes as LDH. Arsenic loading significantly altered stress-induced LDH mRNA expression. LDH mRNA was significantly higher after 12 and $24 \mathrm{~h}$ in the unexposed group. Inhibition of LDH activity during arsenic sublethal treatment may be due to impaired carbohydrate metabolism. Abston and Yarbrough (1976) suggested that any changes in protein and carbohydrate metabolism might cause change in LDH activity.

Almeida et al. (2001, 2002) observed after sublethal concentrations of cadmium a decrease of the LDH activity in white muscle of Oreochromis niloticus, indicating decreases in the capacity of glycolysis in this tissue. On the other hand, Couture and Kumar (2003) not found evidences that Cd inhibit LDH. Cheney and Criddle (1996) suggested in mollusc Elliptio complanata that anaerobic metabolism was less sensitive than aerobic metabolism to metal inhibition. It can be that decreased in aerobic capacity may be compensated by increased anaerobic capacities as well (Rajotte and Couture, 2002). Whether, an increased reliance on anaerobic metabolism confers a bionergetic disadvantage to wild fish remains to be demonstrated.

In relation to the $\mathrm{Zn}$, Radhakrishnaiah et al. (1993) observed in Cyprinus carpio exposed to Zinc a LDH activity in muscle increased. On the other hand Nemcsók and Boross (1982) no observed effects on serum LDH activity of three fish species (carp, silver carp, European wels) after $10 \mathrm{ppm} \mathrm{ZnCl} 2$ exposure maybe. On prolonged exposure zinc-exposed fish could adapt to sublethal toxic stress.

Dobryszycka and Owczarek (1981) following subacute intoxication of rats with $\mathrm{Pb}-, \mathrm{Cu}-$, and $\mathrm{Zn}$-salts (separately or in mixture) for 5 weeks, (LDH) estimated in serum and in cytoplasmic fraction of the kidney. LDH activity was no affect; however, mixture of these metals caused a significant rise in the enzymatic activity. But in the experiments in vitro, $\mathrm{Zn}^{2+}$ inhibited significantly the kidney LDH activity. The results indicated the dependency of zinc-exposed fish on both the oxidative and anaerobic glycolytic pathways in order to meet the energy requirements but different responses are observed in function of several factors such as species, tissue, type of experiment (in vitro and/or in vivo), presence of other metals, etc. Scarce information about $\mathrm{Zn}$ and LDH activity in fish species has been founded. A deep research it would be necessary.

\section{Conclusions}

The present results do not demonstrate biomarkers studied in $S$. senegalensis as sensitive tools to measure exposure to PAHs. On the other hand, significant differences were observed in AChE and IDH activities in muscle of fish from Tinto and Odiel Rivers suggesting that those parameters can be considered good biomarkers. The results obtained in this investigation could be very useful for defining pollution control policies and conservation strategies.

\section{Acknowledgements}

This work has been supported by Project SEAPAT: "Biomarkers and histopathology in gilthead seabream, Sparus aurata, and Senegal sole, Solea senegalensis" (CICYT, REN 2003-09361-CO3-03).

\section{References}

Abston, P.A., Yarbrough, J.D., 1976. The in vivo effect of mirex on soluble hepatic enzymes in the rat. Pestic. Biochem. Physiol. 6, 192-199.

Akaishi, F.M., Silva de Assis, H.C., Jakobi, S.C.G., Eiras-Stofella, D.R., St-Jean, S.D., Courtenay, S.C., Lima, E.F., Wagener, A.L.R., Scofield, A.L., Oliveira Riveiro, C.A. 2004. Morphological and neurotoxicological findings in tropical freshwater fish (Astyanax sp.) after waterborne and acute exposure to water soluble fraction (WSF) of crude oil. Arch. Environ. Contam. Toxicol. 46, 244-253.

Almeida, J.A., Novelli, E.L.B., Dal Pai Silva, M., Alves Júnior, R., 2001. Environmental cadmium exposure and metabolic responses of the Nile tilapia, Oreochromis niloticus. Environ. Pollut. 114, 169-175.

Almeida, J.A., Diniz, Y.S., Marques, S.F.G., Faine, L.A., Ribas, B.O., Burneiko, R.C. Novelli, E.L.B., 2002. The use of the oxidative stress responses as biomarkers in Nile tilapia (Oreochromis niloticus) exposed in vivo to cadmium contamination. Environ. Int. 27, 673-679.

Almeida, J.R., Oliveira, C., Gravato, C., Guilhermino, L., 2010. Linking behavioural alterations with biomarkers responses in the European seabass Dicentrarchus labrax L. exposed to the organophosphate pesticide fenitrothion. Ecotoxicology 19 (8), 1369-1381.

Almeida, J., Gravato, C., Guilhermino, L., 2012. Challenges in assessing the toxic effects of polycyclic aromatic hydrocarbons to marine organisms: A case study on the acute toxicity of pyrene to the European seabass (Dicentrarchus labrax L.). Chemosphere 86, 926-937.

Antognelli, C., Romani, R., Baldracchini, F., De Santis, A., Andreani, G., Talesa, V. 2003. Different activity of glioxalase system enzymes in specimens of Sparus auratus exposed to sublethal copper concentrations. Chem. Biol. Interact. 142 297-305.

Azcue, J.M., 1993. Metales en Sistemas Biológicos: Metales en el medio Ambiente, Ed. PPU, Barcelona.

Ballesteros, M.L., Durando, P.E., Nores, M.L., Díaz, M.P., Bistoni, M.A., Wunderlin, D.A., 2009. Endosulfan induces changes in spontaneous swimming activity and acetylcholinesterase activity of Jenynsia multidentata (Anablepidae Cyprinodontiformes). Environ. Pollut. 157, 1573-1580.

Bast, A., 1996. Anatomy and toxicological pathology of the nervous system. In: Niesink, J.M., de Vries, J., Hollinger, M.A. (Eds.), Toxicology: Principles and Applications. CRC Press, New York, pp. 974-1001.

Bears, H., Richards, J.G., Schulte, P.M., 2006. Arsenic exposure alters hepatic arsenic species composition and stress-mediated gene expression in the common killifish (Fundulus heteroclitus). Aquat. Toxicol. 77 (3), 257-266.

Beauvais, S.L., Jones, S.B., Parris, J.T., Brewer, S.K., Little, E.E., 2001. Cholinergic and behavioural neurotoxicity of carbaryl and cadmium to larval rainbow trout (Oncorhynchus mykiss). Ecotoxicol. Environ. Saf. 49, 84-90.

Bonacci, S., Corsi, I., Focardi, S., 2009. Cholinesterases in the Antartic scallop Adamussium colbecki: characterization and sensitivity to pollutants. Ecotoxicol Environ. Saf. 72, 1481-1488.

Bocquené, G., Galgani, F., Truquet, P., 1990. Characterization and assay conditions for use of AChE activity from several marine species in pollution monitoring. Mar. Environ. Res. 30, 75-89.

Brewer, S.K., Little, E.E., Delonay, A.J., Beauvais, S.L., Jones, S.N., Ellersieck, M.R. 2001. Behavioural dysfunction correlate to altered physiology in rainbow trout (Oncorhynchus mykiss) exposed to cholinesterase-inhibiting chemicals. Arch. Environ. Contam. Toxicol. 40, 70-76.

Cánovas, C.R., Olías, M., Nieto, J.M., Sarmiento, A.M., Cerón, J.C., 2007. Hydrochemical characteristics of the Tinto and Odiel Rivers (SW Spain) Factors controlling metal contents. Sci. Total Environ. 373, 363-382.

Castro, B., Sobral, O., Guilhermino, L., Ribeiro, R., 2004. An in situ bioassay integrating individual and biochemical responses using small fish species. Ecotoxicology 13, 667-681.

CEPA, California Environmental Protection Agency, 1996. State Water Resources Control Board Water Quality: State Mussel Watch Program 1995-97. Data Report. Appendix V, <http://www.swrcb.ca.gov/programs/smw/smW9597. html>.

Cheney, M.A., Criddle, R.S., 1996. Heavy metal effects on the metabolic activity of Elliptio complanata: a calorimetric method. J. Environ. Qual. 25, 235-240.

Conell, D.W., Miller, G.J., 1984. Chemistry and Ecotoxicology of Pollution. WilleyInterscience Publishers, USA, 444pp.

Costa, P.M., Diniz, M.S., Caeiro, S., Lobo, J., Martins, M., Ferreira, A.M., Caetano, M., Vale, C., Del Valls, T.A., Costa, M.H., 2009. Histological biomarkers in liver and 
gills of juvenile Solea senegalensis exposed to contaminated estuarine sediments: a weighted indices approach. Aquat. Toxicol. 92 (3), 202-212.

Couture, P., Kumar, P.R., 2003. Impairment of metabolic capacities in coper and cadmium contaminated wild yellow perch (Perca flavescens). Aquat. Toxicol. 64, 107-120.

Davidson, M.C., Lorna, E.W., Ure, A.M., 1999. Effect of sample preparation on the operational speciation of cadmium and lead in freshwater sediment. Fresenius J. Anal. Chem. 363, 134-136.

De la Torre, F.R., Ferrari, L., Saliián, A., 2002. Freshwater pollution biomarker: response of brain acetylcholinesterase activity in two fish species. Comp. Biochem. Physiol. C 131, 271-280.

De Luca, G., Furesi, A., Leardi, R., Micera, G., Panzanelli, A., Costantina Piu, A., Pilo, M.I., Spano, N., Sanna, G., 2005. Naure, distribution and origin of polycyclic aromatic hydrocarbons assessment in the sediments of Olbia Harbor (Northern Sardinia, Italy). Mar. Pollut. Bull. 50, 1223-1232.

Demirak, A., Yilmaz, F., Levent Tuna, A., Ozdemir, N., 2006. Heavy metals in water, sediment and tissues of Leuciscus cephalus from a stream in southwestern Turkey. Chemosphere 63, 1451-1458.

Diamantino, T.C., Almeida, E., Soares, A.M.V.M., Guilhermino, L., 2001. Lactate dehydrogenase activity as an effect criterion in toxicity tests with Daphnia magna Straus. Bull. Environ. Contam. Toxicol. 57, 979-985.

Dinis, M.T., 1992. Aspects of the potential of Solea senegalensis Kaup for aquaculture: larval rearing and weaning to an artificial diet. Aquacult. Fish. Manage. 23, 179183.

Drake, P., Arias, A.M., Rodríguez, A., 1984. Cultivo extensivo de peces marinos en los esteros de las salinas de San Fernando (Cádiz): II. Características de la producción de peces. Fish. Res. Inst. (Spain) 116, 1-23 (Technical Report).

Dobryszycka, W., Owczarek, H., 1981. Effects of lead, copper, and zinc on the rat's lactate dehydrogenase in vivo and in vitro. Arch. Toxicol. 48 (1), 21-27.

EC, 2006. Comisión Regulation No. 1881/2006 of December 19, 2006 setting maximum levels for certain contaminants in foodstuffs. DOCE, L 364/5-L 364/ 24.

Eisler, R., 2007. Encyclopaedia of Environmental Hazardous Priority Chemicals, first ed. Elsevier Ed., Amsterdam (The Netherlands).

Ellis, G., Goldberg, D.M., 1971. An improved manual and semiautomatic assay for NADP-dependent isocitrate dehydrogenase activity, with a description of some kinetic properties of human liver and serum enzyme. Clin. Biochem. 2, 175-185.

Ellman, G.L., Courtney, K.D., Andres Jr., V., Feather-Stone, R.M., 1961. A new and rapid colorimetric determination of acetylcholinesterase activity. Biochem. Pharmacol. 7, 88-95.

Fernández-Vega, C., Sancho, E., Ferrando, M.D., Andreu, E., 2002. Thiobencarbinduced changes in acetylcholinesterase activity of the fish Anguilla anguilla. Pestic. Biochem. Physiol. 72, 55-63.

Förstner, U., Wittmann, G.T.W., 1983. Metal Pollution in the Aquatic Environment second revised ed. Springer-Verlag, Berlin.

Fulton, M.H., Key, P.B., 2001. Acetylcholinesterase inhibition in estuarine fish and invertebrates as an indicator of organophosphorous insecticide exposure and effects. Environ. Toxicol. Chem. 20 (1), 37-45.

Gagnon, M.M., Holdway, D.A., 2000. EROD induction and biliary metabolite excretion following exposure to the water accommodated fraction of crude oil and to chemically dispersed crude oil. Arch. Environ. Contam. Toxicol. 38 (1) 70-77.

Gill, T.S., Tewari, H., Pande, J., 1990. Use of the fish enzyme system in monitoring water quality: effects of mercury on tissue enzymes. Comp. Biochem. Physiol. C 97, 287-292.

Gold-Bouchot, G., Zapata-Pérez, O., Rodríguez-Fuentes, G., Ceja-Moreno, V., del RíoGarcía, M., Chan-Cocom, E., 2006. Biomarkers and pollutants in the Nile Tilapia, Oreochromis niloticus, in four lakes from San Miguel, Chiapas, Mexico. Int. J. Environ. Pollut. 26 (1-3), 129-141

Gravato, C., Guilhermino, L., 2009. Effects of benzo(a)pyrene on seabass (Dicentrarchus labrax L.): biomarkers, growth and behaviour. Hum. Ecol. Risk Assess. 15, 121-137.

Gravato, C., Guimaraes, L., Santos, J., Faria, M., Alves, A., Guilhermino, L., 2010 Comparative study about the effects of pollution on glass and yellow eels (Anguilla anguilla) from the stuaries of Minho, Lima and Douro Rivers (NW Portugal). Ecotoxicol. Environ. Saf. 73, 524-533.

Guilhermino, L., Lopes, M.C., Carvalho, A.P., Soares, A.M.V.M., 1996 Acetylcholinesterase activity in juveniles of Daphnia magna Straus. Bull. Environ. Contam. Toxicol. 57, 979-985.

Hammeren, J., Powers, S., Lawler, J., Crisswell, D., Martin, D., Lowenthal, D., Pollock, M., 1992. Exercise training induced alterations in skeletal muscle oxidative and antioxidant enzyme activity in senescent rats. Int. J. Sports Med. $13,412-416$

Hannam, M.L., Hagger, J.A., Jones, M.B., Galloway, T.S., 2008. Characterisation of esterases as potential biomarkers of pesticide exposure in the lugworm Arenicola marina (Annelida: Polychaeta). Environ. Pollut. 152 (2), 342-350.

Higashi, T., Maruyama, E., Otani, T., Sakamoto, Y., 1965. Studies on the isocitrate dehydrogenase. I. Some properties of isocitrate dehydrogenase of beef heart muscle. J. Biochem. 57 (6), 793-798.

ISQG-PEL, 2001. Canadian Council of Minister of the environment, Canadian sediment quality guidelines for the protection of aquatic life: summary tables. ISBN 1-896997-34-1, 2001.

Ivanina, A.V., Habinck, E., Sokolova, I.M., 2008. Differential sensitivity to cadmium of key mitochondrial enzymes in the eastern oyster, Crassostrea virginica Gmelin (Bivalvia: Ostreidae). Comp. Biochem. Physiol. C: Toxicol. Pharmacol. 148 (1) 72-79.
Jiménez-Tenorio, N., Morales-Caselles, C., Kalman, J., Salamanca, M.J., Gonzalez de Canales, M.L., Sarasquete, C., Del Valls, T.A., 2007. Determining sediment quality for regulatory proposes using fish chronic bioassays. Environ. Int. 33, 474-480.

Jifa, W., Zhiming, Y., Xiuxian, S., You, W., 2006. Response of integrated biomarkers of fish (Lateolabrax japonicus) exposed to benzo(a)pyrene and sodium dodecylbenzene sulfonate. Ecotoxicol. Environ. Saf. 65, 230-236.

Kamer, T.T., 1994. Dutch standards for contaminated sediments. Evaluatienota Water 21 (250), 27-28.

Kopecka, J., Pempkowiak, J., 2004. AChE as biomarker of mussels and fish contamination with chemicals in the Gulf of Gdansk. Ann. Environ. Prot. 6, 99-106.

Laszczyca, P., 1989. The activity of mitochondrial enzymes in the muscles of rats subjected to physical training and subchronical intoxication with lead and zinc. Acta. Physiol. Pol. 40 (5-6), 544-551.

Lavanya, S., Ramesh, M., Kavitha, C., Malarvizhi, A., 2011. Hematological, biochemical and ionoregulatory responses of Indian major carp Catla catla during chronic sublethal exposure to inorganic arsenic. Chemosphere 82 (7), 977-985.

Liao, C.Y., Fu, J.J., Shi, J.B., Zhou, Q.F., Yuan, C.G., Jiang, G.B., 2006. Methylmercury accumulation, histopathology effects, and cholinesterase activity alterations in medaka (Oryzias latipes) following sublethal exposure to methylmercury chloride. Environ. Toxicol. Pharmacol. 22 (2), 225-233.

Lima, I., Moreira, S.M., Osten, J.R., Soares, A.M.V.M., Guilhermino, L., 2007. Biochemical responses of the marine mussel Mytilus galloprovincialis to petrochemical environmental contamination along the Nothwestern coast of Portugal. Chemosphere 66, 1230-1242.

Lionettto, M.G., Caricato, R., Giordano, M.E., Pascariello, M.F., Marinosci, L., Schettino, T., 2003. Integrated use of biomarkers (acetylcholinesterase and antioxidant enzymes activities) in Mytilus galloprovincialis and Mullus barbatus in an Italian coastal marine area. Mar. Pollut. Bull. 46, 324-330.

Lu, G.H., Wang, C., Zhu, Z., 2009. The dose-response relationships for EROD and GST induced by polyaromatic hydrocarbons in Carassius auratus. Bull. Environ. Contam. Toxicol. 82 (2), 194-199.

Müller, L., 1986. Consequences of cadmium toxicity in rat hepatocytes: mitochondrial disfunction and lipid peroxidation. Toxicology 40, 285-295.

Nagaraja, T.N., Desiraju, T., 1994. Effects on operant learning and brain acetylcholine esterase activity in rats following chronic inorganic arsenic intake. Hum. Exp. Toxicol. 13 (5), 353-356.

Nakata, H., Sakai, Y., Miyawaki, T., Takemura, A., 2003. Bioaccumulation and toxic potencies of polychlorinated biphenyls and polycyclic aromatic hydrocarbons in tidal flat and coastal ecosystems of the Ariake Sea. Jpn. Environ. Sci. Technol. 37 (16), 3513-3521.

Napierska, D., Podolska, M., 2006. Field studies of eelpout (Zoarces viviparus L.) from Polish coastal waters (southern Baltic Sea). Sci. Total Environ. 371, 144-155.

Napierska, D., Podolska, M., 2008. Relationship between biomarker responses and contaminant concentration in selected tissues of flounder (Platichthys flesus) from the Polish coastal area of the Baltic Sea. Oceanologia 50 (3), 421-442.

Narbonne, J.F., Djomo, J.E., Ribera, D., Ferrier, V., Garrigues, P., 1999. Accumulation kinetics of polycyclic aromatic hydrocarbons adsorbed to sediment by the mollusk Corbicula fluminea. Ecotoxicol. Environ. Saf. 42, 1-8.

Nemcsók, J., Boross, L., 1982. Comparative studies on the sensitivity of different fish species to metal pollution. Acta Bio. Hung. 33, 23-27.

Oliva, M., Garrido, M.C., Sales Márquez, D., González de Canales, M.L., 2009. Sublethal and lethal toxicity in juvenile Senegal sole (Solea senegalensis) exposed to copper: a preliminary toxicity range-finding test. Exp. Toxicol. Pathol. 61 (2), 113-121.

Osman, A.G.M., Mekkawy, I.A., Verreth, J., Kirschbaum, F., 2007. Effects of lead nitrate on the activity of metabolic enzymes during early developmental stages of the African catfish, Clarias gariepinus (Burchell, 1822). Fish Physiol. Biochem. $33,1-13$.

Payne, J.F., Mathieu, A., Melvin, W., Fancey, L.L., 1996. Acetylcholinesterase, an old biomarker with a new future? Field trials in association with two urban rivers and a copper mill in Newfoundland. Mar. Pollut. Bull. 32 (2), 225-231.

Pretto, A., Loro, V.L., Morsch, V.M., Moraes, B.S., Menezes, C., Clasen, B., Hoehne, L., Dressler, V., 2010. Acetylcholinesterase activity, lipid peroxidation, and bioaccumulation in silver catfish (Rhandia quelen) exposed to cadmium. Arch. Environ. Contam. Toxicol. 58, 1008-1014.

Rabito, I.S., Alves Costa, J.R.M., Silva de Assis, H.C., Pelletier, E. Akaishi, F.M. Anjos, A., Randi, M.A.F., Oliveira Ribeiro, C.A., 2005. Effects of dietary PB (II) and tributyltin on neotropical fish, Hoplias malabaricus: histopathological and biochemical findings. Ecotoxicol. Environ. Saf. 60 (2), 147-156.

Radhakrishnaiah, K., Suresh, A., Sivaramakrishna, B, 1993. Effect of sublethal concentration of mercury and zinc on the energetic of a freshwater fish Cyprinus carpio (Linnaeus). Acta Biol. Hung. 44 (4), 375-385.

Rajotte, J.W., Couture, P., 2002. Effects of environmental metal contamination on the condition, swim performance and tissue metabolic capacities of wild yellow perch (Perca flavescens). Can. J. Fish. Aquat. Sci. 59, 1296-1304.

Reddy, A.S., Reddy, M.V., Radhakrishnaiah, K., 2008. Impact of copper on the oxidative metabolism of the fry of common carp, Cyprinus carpio (Linn.) at different pH. J. Environ. Biol. 29 (5), 721-724.

Rendon von Osten, J., Ortiz-Arana, A., Guilhermino, L., Soares, A.M., 2005. In vivo evaluation of three biomarkers in the mosquitofish (Gambusia yucatana) exposed to pesticides. Chemosphere 58, 627-636.

Roche, H., Buet, A., Ramde, F., 2002. Accumulation of lipophilic microcontaminants and biochemical responses in eels from the Camargue biosphere reserve. Ecotoxicology 11, 155-164. 
Romani, R., Antognelli, C., Baldracchini, F., De Santis, A., Isani, G., Giovannini, E., Rosi, G., 2003. Increased acetylcholinesterase activities in specimens of Sparus auratus exposed to sublethal coper concentrations. Chem. Biol. Interact. 145, 321-329.

Roy, L.A., Steinert, S., Bay, S.M., Greenstein, D., Sapozhnikova, Y., Bawardi, O., Leifer I., Schlenk, D., 2003. Biochemical effects of petroleum exposure in hornyhead turbot (Pleurnichthys verticalis) exposed to a gradient of sediments collected from a natural petroleum seep in CA, USA. Aquat. Toxicol. 65, 159-169.

Shao, Y., Jiang, L.N., Zhang, D.J., Ma, L.J., Li, C.X., 2011. Effects of arsenic, cadmium and lead on growth and respiratory enzymes activity in wheat seedlings. Afr. J. Agric. Res. 6 (19), 4505-4512.

Sancho, E., Fernandez-Vega, C., Villarroel, M.J., Andreu-Moliner, E., Ferrando, M.D. 2009. Physiological effects of tricyclazole on zebrafish (Danio rerio) and postexposure recovery. Comp. Biochem. Physiol. 150, 25-32.

Sarmiento, A.M., Nieto, J.M., Casiot, C., Elbaz-Poulichet, F., Egal, M., 2009. Inorganic arsenic speciation at river basin scales: the Tinto and Odiel Rivers in the Iberian Pyrite Belt, SW Spain. Environ. Pollut. 157, 1202-1209.

Schrap, S.M., Opperhuizen, A., 1990. Relationship between bioavailability and hydrophobicity: reduction of the uptake of organic chemicals by fish due to the sorption on particles. Environ. Toxicol. Chem. 9, 715-724.

Silva, C.A., Oliveira Ribeiro, C.A., Katsumiti, A., Araújo, M.L.P., Zandoná, E.M., Costa Silva, G.P., Maschio, J., Roche, H., Silva de Assis, H.C., 2009. Evaluation of waterborne exposure to oil spill 5 years after an accident in southern Brazil. Ecotoxicol. Environ. Saf. 72, 400-409.

Solé, M., Lima, D., Reis-Henriques, M.A., Santos, M.M., 2008. Stress biomarkers in juvenile Senegal sole, Solea senegalensis, exposed to the water-accommodated fraction of the "Prestige" fuel oil. Bull. Environ. Contam. Toxicol. 80, 19-23.

Spies, R.B., Davis, P.H., Stuerner, D.H., 1980. Ecology of a petroleum seep off the California coast. In: Geyer, R. (Ed.), Marine Environmental Pollution. Elsevier, Amsterdam, pp. 229-263.

Szavó, A., Nemcsók, J., Aztalos, B., Rakkonczay, Z., Kása, P., Hieu, L.H., 1992. The effect of pesticides on carp (Cyprinus carpio). Acetylcholinesterase and its biochemical characterization. Ecotoxicol. Environ. Saf. 23, 39-45.

Tintos, A., Gesto, M., Míguez, M.J., Soengas, J.L., 2008. B-Naphthoflavone and benzo(a)pyrene treatment affect liver intermediary metabolism and plasma cortisol levels in rainbow trout Oncorhynchus mykiss. Ecotoxicol. Environ. Saf. $69,180-186 .^{2+}$
Toury, R., Stelly, N., Boissonneau, E., Dupois, Y., 1985. Degenerative processess in skeletal muscle of $\mathrm{Cd}^{2+}$ - treated rats and $\mathrm{Cd}^{2+}$ inhibition of mitochondrial $\mathrm{Ca}^{2+}$ transport. Toxicol. Appl. Pharmacol. 77, 19-35.

USEPA, United States Environmental Protection Agency, 1996. Method 3540C: Soxhlet extraction. <http://www.epa.gov>.

USEPA, United States Environmental Protection Agency, 2000. Method 3620C: Florisil cleanup. <http://www.epa.gov>.

USEPA, United States Environmental Protection Agency, 2002. National Recommended Water Quality Criteria. EPA-822-R-02-047, Office of Science and Technology.

Vaglio, A., Landriscina, C., 1999. Changes in liver enzyme activity in the teleost Sparus aurata in response to cadmium intoxication. Ecotoxicol. Environ. Saf. 43. 11-116.

Van der Oost, R., Beyer, J., Vermeulen, N.P.E., 2003. Fish bioaccumulation and biomarkers in environmental risk assessment: a review. Environ. Toxicol. Pharmacol. 13, 57-149.

Vassault, A., 1983. Lactate dehydrogenase. In: Bergmeyer, H.V. (Ed.), Methods in enzymatic analysis, vol. 3. Verlag Chemie, Weinheim, pp. 118-126.

Vicente-Martorell, J.J., Galindo-Riano, M.D., Garcia-Vargas, M., Granado-Castro, M.D., 2008. Heavy metal speciation of estuarine sediments affected by acid mine drainage in the Tinto and Odiel estuary, Spain. Relationship to bioconcentration of fish tissues. Fresenius Environ. Bull. 17 (10B), 1744-1754.

Vicente-Martorell, J.J., Galindo-Riaño, M.D., García-Vargas, M., Castro-Granado, M.D., 2009. Bioavailability of heavy metals monitoring water, sediments and fish species from a polluted estuary. J. Hazard. Mater. 162, 823-836.

Vieira, L R Sousa, A Frasco, M.F. Lima, I. Morgado, L Guilhermino, L, 2008. Accute effects of benzo(a)pyrene, anthracene and a fuel oil on biomarkers of the common goby Pomatochistus microps (Teleostei, Gobiidae). Sci. Total Environ. 395, 87-100.

Vieira, L.R., Gravato, C., Soares, A.M.V.M., Morgado, F., Guilhermino, L., 2009. Acute effects of copper and mercury of the estuarine fish Pomatochistus microps: linking biomarkers to behaviour. Chemosphere 76, 1416-1427.

Whitehead, A, Anderson, S.L., Ramirez, A.,Wilson, B.W. 2005. Cholinesterases in aquatic biomonitoring: assay optimization and species-specific characterization for a California native fish. Ecotoxicology 14, 597-606.

Yang, G.P., 2000. Polycyclic aromatic hydrocarbons in the sediments of the South China Sea. Environ. Pollut. 108, 163-171. 